\title{
Monte Carlo Numerical Method \\ in the Problem of Temperature Stability Analysis of Electronic Devices
}

\author{
Denis V. Ozerkin*a and Sergey A. Rusanovskiy ${ }^{\mathrm{b}}$ \\ ${ }^{a}$ Tomsk State University of Control Systems and Radioelectronics \\ 40 Lenin, Tomsk, 634050, Russia \\ ${ }^{b}$ Polus, JSC \\ 56 v Kirov, Tomsk, 634050, Russia
}

Received 04.10.2017, received in revised form 02.01.2018, accepted 06.05.2018

The problem of ensuring high temperature stability of parameters by reason of the characteristic features inherent in the integral performance becomes especially urgent for microminiature electronic devices. For the mathematical description of the electronic devices' temperature error it is proposed to use the method of experiment's statistical planning in combination with regression analysis. There are classes of electrical circuits in which the output parameter depends mainly on one-parameter electrical radio elements. In the article it is shown that the problem of obtaining the temperature error equation for such electrical circuits can be reduced to the problem of effective finding of the one-parameter electro radio elements' influence coefficients. A modification of the Monte Carlo statistical method with the computational factor experiment's scenario to find the temperature error equation is considered. Approbation of the proposed modification is carried out using the example of the electric circuit of the generator with the Wien bridge.

Keywords: electronic device, electrical radio elements, temperature stability, circuit simulator, SPICE model, factor experiment, regression analysis, Monte Carlo statistical method, temperature error equation.

Citation: Ozerkin D.V., Rusanovskiy S.A. Monte Carlo numerical method in the problem of temperature stability analysis of electronic devices, J. Sib. Fed. Univ. Eng. technol., 2018, 11(5), 512-527. DOI: 10.17516/1999-494X-0050.

(C) Siberian Federal University. All rights reserved

* Corresponding author E-mail address: ozerkin.denis@yandex.ru, rusa10@yandex.ru 


\title{
Численный метод Монте-Карло
}

\section{в задаче анализа температурной стабильности электронных средств}

\author{
Д.В. Озеркин ${ }^{a}$, С.А. Русановский \\ ${ }^{a}$ Томский государственный университет систем управления \\ и радиоэлектроники \\ Россия, 634050, Томск, пр. Ленина, 40 \\ ${ }^{\sigma} \mathrm{AO}$ «НПЦ «Полюс» \\ Россия, 634050, Томск, пр. Кирова, 56 в
}

Для микроминиатюрных электронных средств особенно актуальной становится задача обеспечения высокой температурной стабильности параметров в связи с характерными особенностями, присущими интегральному исполнению. Для математического описания температурной погрешности электронных средств предлагается использование метода статистического планирования эксперимента в сочетании с регрессионным анализом. Существуют классы электрических схем, в которых выходной параметр зависит в основном от однопараметрических электрорадиоизделий. $B$ статье показано, что задачу получения уравнения температурной погрешности для таких электрических схем можно свести к задаче эффективного нахождения коэффициентов влияния $a_{i}$ однопараметрических электрорадиоизделий. Рассмотрена модификаиия статистического метода Монте-Карло по сиенарию вычислительного факторного эксперимента для нахождения уравнения температурной погрешности. Проведена апробачия предложенной модификаџии на примере электрической схемы генератора с мостом Вина.

Ключевые слова: электронное средство, электрорадиоизделия, температурная стабильность, схемотехнический симулятор, SPICE-модель, факторный эксперимент, статистический метод Монте-Карло, регрессионный анализ, уравнение температурной погрешности.

\section{Introduction}

A significant place in the modern electronic devices' (ED) design is the task of ensuring the temperature stability of ED parameters under both external (environment) and internal (heat generation in electrical radio elements) thermal effects. The new element base and constructive material use, the new technological operation implementation lead to an essential reduction in the ED mass and volume. In general it affects the operational, design, technological and economic indicators positively. At the same time, for microminiature ED, the problem of ensuring parameters' high temperature stability becomes especially urgent, due to the characteristic features inherent in the integral design: the increase in the specific dissipated power of electrical radio elements (ERE), the mutual parameter correlation, the heat transfer complex mechanism, etc.

The earliest domestic publication on the ED thermal stability is work [1]. The book provides a detailed error analysis arising in the ED production process. Based on analysis, the book authors propose a technique for calculating the radioelectronic equipment tolerances. The technique involves a combine use of the electrical tolerance theory, probability theory and mathematical statistics. As an 
approbation of the proposed methodology, the book authors give estimates of tolerances for several typical electrical circuits operating in a continuous and pulsed mode. The direct current electrical circuits are considered separately.

In a later paper [2], the calculating tolerance technique proposed in [1] was found to be a logical extension. The technique served to form the ED mechanical and electrical tolerance theory. The global mathematical model in this theory is the relative error equation of $N$ ED output parameter:

$$
\frac{\Delta N}{N}=\sum_{i=1}^{n}\left[\frac{\partial \varphi_{i}\left(q_{1}, q_{2}, \ldots, q_{n}\right)}{\partial q_{i}} \frac{q_{i}}{\varphi_{i}\left(q_{1}, q_{2}, \ldots, q_{n}\right)} \alpha_{i}\right] \Delta T
$$

where $\frac{\partial \varphi\left(q_{1}, q_{2}, \ldots, q_{n}\right)}{\partial q_{i}} \frac{q_{i}}{\varphi\left(q_{1}, q_{2}, \ldots, q_{n}\right)}=B_{i}-$ are the influence coefficients; $\alpha_{i}-$ is the temperature coefficient of $i$-th ERE parameter; $\Delta T$ - is the difference between the ERE operating temperature and the ambient temperature; $q_{1}, q_{2}, \ldots, q_{n}$ - are ERE parameters; $\phi\left(q_{1}, q_{2}, \ldots, q_{n}\right)$ - is the analytical dependence of $N$ ED output parameter versus the ERE parameters.

Further development of the ED electric tolerance theory with reference to external and internal temperature influences was found in [3]. The author proposed an effective method for finding the $B_{i}$ influence coefficients of the temperature error equation (1). The essence of the method is the use of experimental statistical planning in combination with regression analysis. In this case the global mathematical model is the regression equation:

$$
n=b_{0}+\sum_{i=1}^{k} b_{i} q_{i}+\sum_{i<j}^{k} b_{i j} q_{i} q_{j}+\sum_{i=1}^{k} b_{i i} q_{i}^{2}+\ldots,
$$

where $n$-statistical evaluation of $N$ ED output parameter; $b_{0}, b_{i}, b_{i j}, b_{i i}$ - are the empirical coefficients of the regression equation.

The regression equation (2) makes it possible to estimate both linear and nonlinear interactions, depending on the experimental plan.

In the same paper [3] it was shown that for multiparameter ERE it is expedient to make a variation not by individual parameters but directly affect $i$-th element by temperature. If during statistical data processing we additionally normalize the regression coefficients in (2), then we obtain the temperature error equation:

$$
\frac{\Delta N_{\text {out }}}{N_{\text {out }}}=\sum_{i=1}^{n} a_{i} \frac{\Delta T_{i}}{T_{i}}+\sum_{i=1}^{n} \sum_{j=1}^{n} a_{i} a_{j} \frac{\Delta T_{i}}{T_{i}} \frac{\Delta T_{j}}{T_{j}}+\ldots,
$$

where $a_{i}=\frac{b_{i} \cdot T_{0}}{\Delta T \cdot b_{0}}-$ is the influence coefficient of the $i$-th ERE; $T_{0}-$ is the nominal temperature (zero variation level); $\Delta T$-is the temperature variation interval; $\frac{\Delta T_{i}}{T_{i}}$-relative change in the ERE operating
temperature.

The practical use of the temperature error equation (3) was demonstrated in [4, 5]. In particular, a regression analysis of the electronic circuit temperature stability was developed using computer circuit simulators, such as Cadence OrCAD and Spectrum Software MicroCAP. 


\section{Problem statement}

According to the investigation results in $[4,5]$ it was established that the variation in the ERE operating temperature in the factor experiment is not always justified. There are electrical circuit classes in which $N$ ED output parameter depends on one-parameter ERE (resistors, capacitors, inductors) mainly. Therefore, when carrying out a factor experiment it is sufficient to vary by one parameter for each such ERE. There is no need to take into account the temperature dependence of the interrelated (correlated) parameter complex within one ERE. Based on this, equation (1) takes the form:

$$
\frac{\Delta N}{N}=\sum_{i=1}^{n}\left[\frac{\partial \varphi_{i}\left(q_{i}\right)}{\partial q_{i}} \frac{q_{i}}{\varphi_{i}\left(q_{i}\right)} \alpha_{i}\right] \Delta T .
$$

The difference in the experiment planning course lies in another mechanism for obtaining a normalization factor:

$$
Q_{i}=\frac{q_{i}-q_{i 0}}{\left|q_{i}-q_{i 0}\right|}, Q_{i}= \pm 1
$$

where $\Delta q_{i}=\left(q_{i}-q_{i 0}\right)$ - is the variation interval (step) of $i$-th ERE parameter.

Applying the differentiation operation to (4) for each $q_{i}$ factor, we obtain the temperature error equation according to [2]:

$$
\frac{\Delta N}{N}=\left[\sum_{i=1}^{k} A_{i} \alpha_{q_{i}}+\sum_{i<j}^{k} A_{i j} \alpha_{q_{i}} \alpha_{q_{j}}+\sum_{i=1}^{k} A_{i i}\left(\alpha_{q_{i}}\right)^{2}+\ldots\right] \Delta T,
$$

where $A_{i}=\frac{\partial N}{\partial q_{i}} \frac{q_{i 0}}{N_{0}}-$ is the influence coefficient of linear terms; $A_{i j}=\frac{\partial^{2} N}{\partial q_{i} \partial q_{j}} \frac{q_{i 0} q_{j 0}}{N_{0}}-$ is the mixed second-order influence factor characterizing the $(i-j)$ pair factor interaction on the output parameter; $A_{i i}=\frac{\partial^{2} N}{\partial^{2} q_{i}} \frac{q_{i 0}^{2}}{N_{0}}-$ second-order influence coefficient.

In the final form, the temperature error equation for one-parameter ERE is:

$$
\frac{\Delta N_{\text {out }}}{N_{\text {out }}}=\sum_{i=1}^{n} a_{i} \alpha_{i} \Delta T_{i}+\sum_{i=1}^{n} \sum_{j=1}^{n} a_{i j} \alpha_{i} \alpha_{j} \Delta T_{i} \Delta T_{j}+\ldots,
$$

where $a_{i}$ - is the influence coefficient of $i$-th ERE thermal dependent parameter; $b_{i}-$ regression coefficient; $\alpha_{i}$ - maximum temperature coefficient value of the variable parameter; $\Delta T_{i}$ - working temperature changing of $i$-th ERE.

Thus, the problem of obtaining equation (7) can be reduced to the problem of efficiently finding the $a_{i}$ coefficients for electronic devices, at that temperature function of the $N$ output parameter depends primarily on one-parameter electro radio elements.

\section{Research theory part}

The aim of the research is to improve the system design method of the thermostable ED with the numerical Monte Carlo method. 
A common method of electrical circuits' statistical analysis is the Monte Carlo method (the statistical test method) [6]. At the same time, the use of this method as applied to the study of the ED temperature stability generates two main problems:

1. Search or synthesis of ERE mathematical models by criterion of adequacy of parameters' temperature dependences to their real characteristics.

2. Monte Carlo method realization according to the factor experiment scenario in order to justify minimization of the statistical test number.

The complexity of first problem solving is due to the fact that there are practically no adequate ERE mathematical models with parameters' temperature dependences applied to the domestic element base. Separate attempts to create such models have been undertaken in [7, 8]. This article focuses on solving the second problem - the implementation of the numerical Monte Carlo method in the problem of analyzing the ED's temperature stability.

The calculation block diagram using the Monte Carlo method (Fig. 1) includes the basic procedures:

1. Random $\mathbf{Q}$ vector realization, i.e. generation of $q_{i}$ component parameters' random values in accordance with their distribution laws.

2. A single-variant analysis of the electrical circuit with the obtained random $\mathbf{Q}$ vector realization.

3. Calculation of the target $V$ function's value in order to establish the ED output parameter.

4. Pre-set repetition of procedures No. 1, 2, 3, corresponding to the total test's number.

5. Statistical processing of the all tests' results.

Approaches in the implementation of No. 1, 3, 5 procedures are specific for the numerical Monte Carlo method in the problem of analyzing the ED's temperature stability. Let us consider this implementation in more detail.

It is known [9] that for single-parameter ERE (resistors, capacitors, inductors), the temperature coefficient characterizes reversible changes in the $q$ parameter with a change in temperature. The parameter's temperature coefficient (PTC) $\alpha_{q}$ - is its relative change with temperature change by $1{ }^{\circ} \mathrm{C}$ :

$$
\alpha_{q}=\frac{1}{q} \frac{d q}{d T}
$$

With a parameter's linear temperature dependence, which is usually observed in a narrow range of ambient temperatures, the PTC calculates as:

$$
\alpha_{q}=\frac{q(T)-q\left(T_{0}\right)}{q\left(T_{0}\right)\left(T-T_{0}\right)},
$$

where $q(T), q\left(T_{0}\right)$ - is the parameter's value, respectively, at an increased (decreased) operating temperature $T$ and at a normal temperature $T_{0}$.

If the $q(T)$ dependence is nonlinear, then the parameter's temperature stability can be characterized by a relative change in the $\delta q$ parameter:

$$
\delta_{q}=\frac{q(T)-q\left(T_{0}\right)}{q\left(T_{0}\right)} \cdot 100 \% .
$$




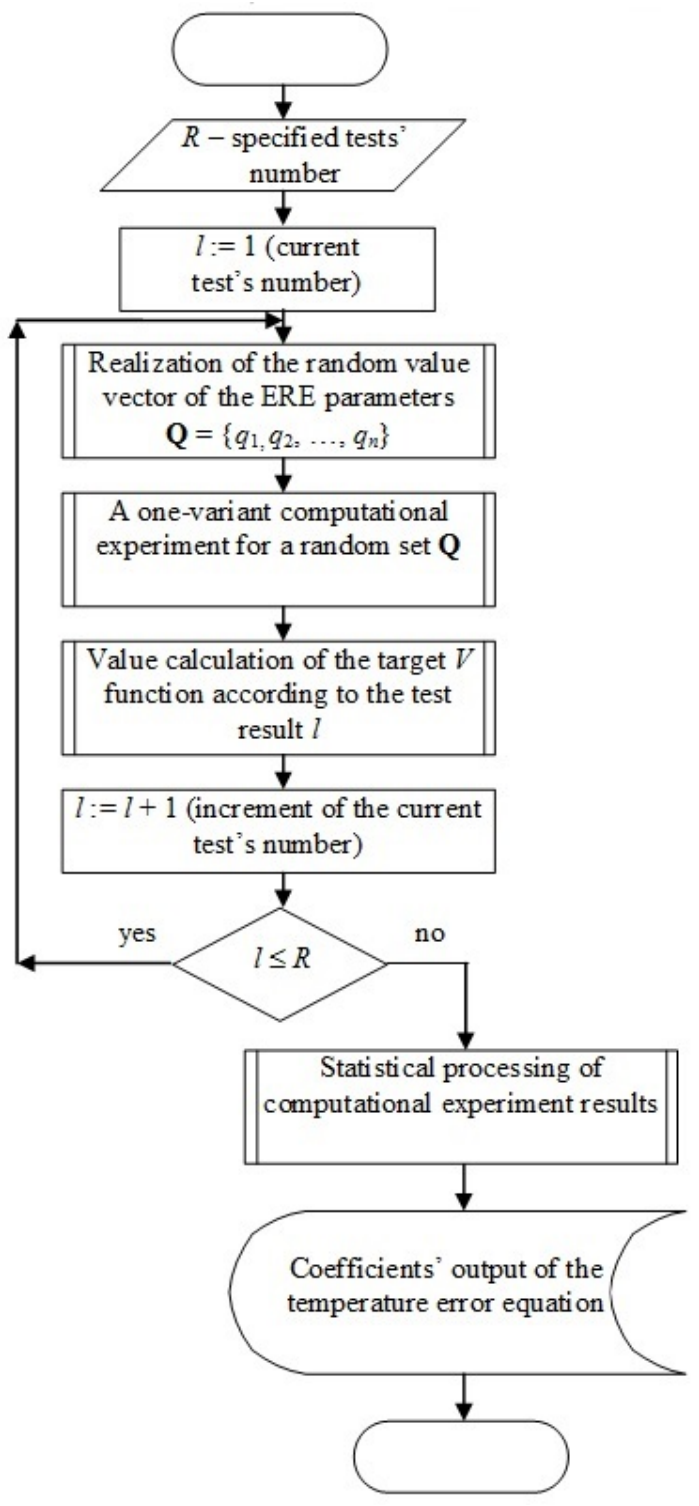

Fig. 1. Block diagram of the computational experiment realization for finding the coefficients of the temperature error equation

Let $i$-th ERE of the electrical circuit have a functional $q_{i j}$ parameters' set (Set ${ }_{i}$ vector):

$$
\mathbf{S e t}_{i}=\left\{q_{i 1}, q_{i 2}, q_{i 3}, \ldots\right\} .
$$

From the position of the temperature stability investigation of $i$-th ERE, each functional parameter is a temperature function. Consequently, $\mathbf{S e t}_{i}$ is also a vector function versus temperature:

$$
\operatorname{Set}_{i}(T)=\left\{q_{i 1}(T), q_{i 2}(T), q_{i 3}(T), \ldots\right\} .
$$

In the special case of one-parameter ERE (elements with one pronounced functional parameter), the vector function degenerates into a one parameter's function versus temperature: 


$$
\operatorname{Set}_{i}(T)=\left\{q_{i}(T)\right\} \rightarrow q_{i}(T) .
$$

The $T$ temperature, inherent in $i$-th one-parameter ERE under both external and internal thermal effects, is probability value. Suppose that the probability $T$ value for $i$-th ERE is subject to the normal distribution law:

$$
f(T)=\frac{1}{\sigma \sqrt{2 \pi}} \exp \left[-\frac{\left(T-T_{0}\right)^{2}}{2 \sigma^{2}}\right],
$$

where $f(T)$ - is the probability density function of the random $T$ value; $T_{0}$ - is the normal temperature; $\sigma-$ is the standard deviation of the random $T$ value.

Define a certain range of operating temperatures for $i$-th ERE: [Tmin, Tmax]. According to the factor experiment scenario [5], the operating $T$ temperature of $i$-th ERE can be equiprobably near the point $T_{0 \min }$ and $T_{0 \max }$ estimates. Then the sum of the probability density functions of a random $T$ value is a bimodal distribution's density function:

$$
b i(T)=\frac{f\left(T_{\min }\right)+f\left(T_{\max }\right)}{n o r m}=\frac{1}{n o r m \sqrt{2 \pi}}\left\{\frac{1}{\sigma_{\min }} \exp \left[-\frac{\left(T_{\min }-T_{0 \min }\right)^{2}}{2 \sigma_{\min }^{2}}\right]+\frac{1}{\sigma_{\max }} \exp \left[-\frac{\left(T_{\max }-T_{0 \max }\right)^{2}}{2 \sigma_{\max }^{2}}\right]\right\},
$$

where norm - is the normalizing coefficient; $T_{\min }$ and $T_{\max }$ - random values of operating temperatures at the given range's boundaries; $\sigma_{\min }$ and $\sigma_{\max }-$ are the corresponding $T_{\min }$ and $T_{\max }$ standard deviations.

Obviously, the computational factor experiment, in contrast to the real experiment, allows us to specify the variation levels' values with high accuracy in each experiment realization. Consequently, under the conditions of the computational factorial experiment: $\left(\sigma_{\min } \approx \sigma_{\max }\right) \rightarrow 0$. This effect is graphically shown in Fig. 2. The bimodal distribution's density function can be written more simply:

$$
b i(T)=\frac{1}{n o r m \cdot \sigma \sqrt{2 \pi}}\left\{\exp \left[-\frac{\left(T_{\min }-T_{0}^{\prime}\right)^{2}}{2 \sigma^{2}}\right]+\exp \left[-\frac{\left(T_{\max }-T_{0}^{\prime \prime}\right)^{2}}{2 \sigma^{2}}\right]\right\} .
$$

The limiting case, when $\sigma=0$, allows us to introduce the discrete random $T$ value's notion, i.e. operating temperature of $i$-th ERE, taking only the $T_{0 \min }$ and $T_{0 \max }$ values. The discrete random $T$ value is determined by the $B i(T)$ distribution function analytically:

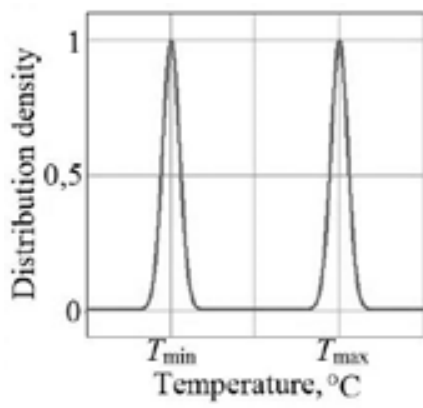

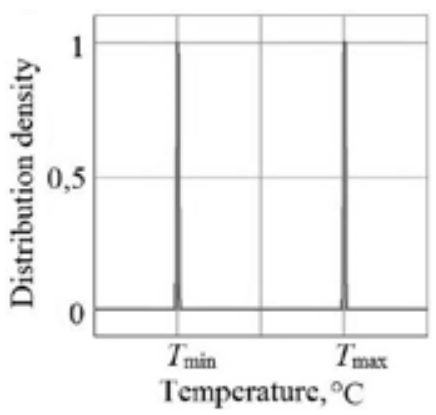

b

Fig. 2. The bimodal distribution's density function of the random $T$ value: $a-(\sigma \neq 0)$ case, $b-(\sigma \rightarrow 0)$ case 


$$
B i(T)=\left\{\begin{array}{l}
0 \in\left(-\infty ; T_{\min }\right] ; \\
0,5 \in\left(T_{\min } ; T_{\max }\right] ; \\
1 \in\left(T_{\max } ;+\infty\right) .
\end{array}\right.
$$

The graphical form of the $B i(T)$ distribution function is shown in Fig. 3.

As a result, for $i$-th ERE function (8), the definition domain consists of only two values:

$$
q_{i}(T)=q_{i}\left\{\begin{array}{l}
T_{\min } \\
T_{\max }
\end{array}\right\} .
$$

The $q_{i}(T)$ function is, in its turn, one of the parameters for the ED's relative error equation (4). Therefore, as applied to equation (4), the admissible parameters for $i$-th ERE are:

$$
Q_{i}=\left\{\begin{array}{c}
q_{i}^{\min } \\
q_{i}^{\max }
\end{array}\right\} .
$$

The computational experiment factors' area is the set of all $q_{i}$ :

$$
\mathbf{Q}=\left\{\begin{array}{l}
Q_{1}=\left\{\begin{array}{l}
q_{1}^{\min } \\
q_{1}^{\max }
\end{array}\right\} ; \\
Q_{2}=\left\{\begin{array}{l}
q_{2}^{\min } \\
q_{2}^{\max }
\end{array}\right\} ; \\
\cdots \\
Q_{n}=\left\{\begin{array}{l}
q_{n}^{\min } \\
q_{n}^{\max }
\end{array}\right\},
\end{array}\right.
$$

where $n$-is the factor number, i.e. the one-parameter ERE number are varied in the experiment.

Under the conditions of realization of the computational factor experiment, a $\mathbf{V}$ vector will be obtained. The $\mathbf{V}$ vector's element is represented by the $\theta_{i}$ function of the ED's one-variant test, which contains a unique (non-repetitive) $q_{i}$ value's combination:

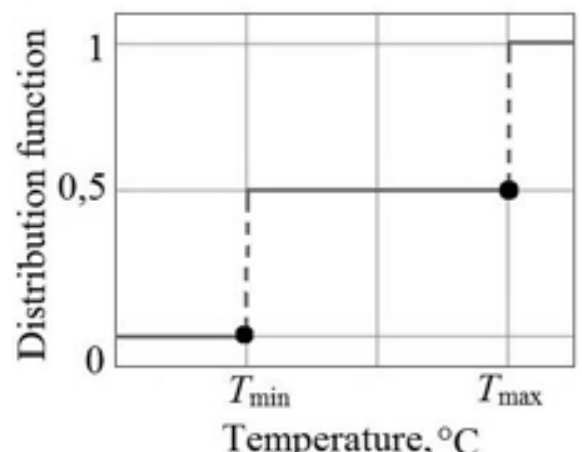

Fig. 3. The distribution function of a discrete random $T$ value 


$$
\mathbf{V}=\left\{\begin{array}{l}
V_{1}=\theta_{1}\left(Q_{1}, Q_{2}, \ldots, Q_{n}\right)=\theta_{1}\left(q_{1}^{\min }, q_{2}^{\min }, \ldots, q_{n}^{\min }\right) ; \\
V_{2}=\theta_{2}\left(Q_{1}, Q_{2}, \ldots, Q_{n}\right)=\theta_{2}\left(q_{1}^{\max }, q_{2}^{\min }, \ldots, q_{n}^{\min }\right) ; \\
\ldots \\
V_{m}=\theta_{m}\left(Q_{1}, Q_{2}, \ldots, Q_{n}\right)=\theta_{m}\left(q_{1}^{\max }, q_{2}^{\max }, \ldots, q_{n}^{\max }\right),
\end{array}\right.
$$

where $m=2^{n}$.

Statistical processing of the computational experiment is aimed at finding the coefficients' regression. We introduce an auxiliary $\mathbf{K}$ matrix with $m \times(n+1)$ dimension containing the code values of variable factors' levels:

$$
\mathbf{K}=\left|\begin{array}{cccc}
1 & -1 & \ldots & -1 \\
1 & -1 & \ldots & 1 \\
\ldots & \ldots & \ldots & \ldots \\
1 & 1 & \ldots & 1
\end{array}\right| .
$$

The zero matrix column (leftmost) contains unit values and is intended to calculate the free term of the regression equation:

$$
b_{0}=\frac{\mathbf{V}^{\mathbf{T}} \cdot \mathbf{K}^{<0>}}{m} .
$$

The remaining columns of the $\mathbf{K}$ matrix (from 1 to $n$ ) serve to calculate the coefficients' regression of the corresponding factor:

$$
b_{1}=\frac{\mathbf{V}^{\mathbf{T}} \cdot \mathbf{K}^{<1>}}{m} ; \ldots ; b_{n}=\frac{\mathbf{V}^{\mathbf{T}} \cdot \mathbf{K}^{<n>}}{m} .
$$

The factors' non-linear interaction in the computational experiment can be taken into account by adding columns with the code realization of the $q_{i} q_{j}, q_{i} q_{j} q_{k}, \ldots$ factors. It is obvious that the nonlinear interaction study will lead to an increase in the dimension of the $\mathbf{K}$ matrix to:

$$
m \times(n+1+p),
$$

where $p$ - is the number of factors' nonlinear interactions.

To find the temperature error equation (7), it is necessary to recalculate the $b_{i}$ coefficients' regression in the $a_{i}$ influence coefficients of the thermally dependent parameter of $i$-th ERE:

$$
a_{i}=\frac{b_{i} \cdot q_{i}^{0}}{\Delta q_{i} \cdot b_{0}}
$$

where $q_{i}^{0}$ - the zero level of the variable parameter of $i$-th ERE; $\Delta q_{i}$ - the variation interval of the $q_{i}^{0}$ value.

\section{Research experiment part}

The object of experimental research is the electric circuit of the harmonic oscillations' generator with the Wien bridge (Fig. 4). The generator uses VD1 and VD2 zener diodes to limit the output signal. 


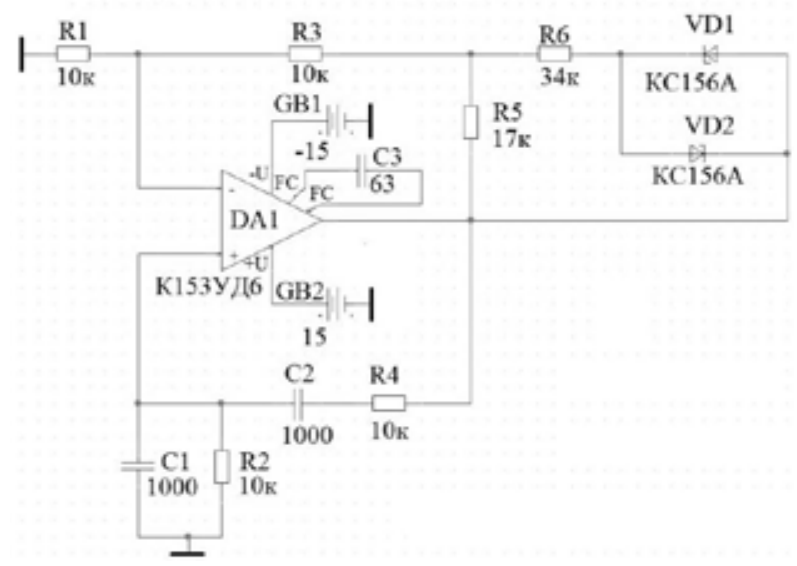

Fig. 4. Wien bridge circuit

The circuit is characterized by a harmonic distortion coefficient in the range $1 \ldots 5 \%$ [10]. To generate oscillations in the generator, the Barkhausen criterion must be complied: the phase shift of $180^{\circ}$ occurs in the feedback loop; the total gain in the loop is not less than one.

In the circiut $\mathrm{R} 2=\mathrm{R} 4=\mathrm{R}$ and $\mathrm{C} 1=\mathrm{C} 2=\mathrm{C}$. Consequently, the theoretical quasi-resonance frequency is:

$$
f=\frac{1}{2 \pi R C}=\frac{1}{2 \pi \cdot 10^{4} \cdot 10^{-9}}=15923 \mathrm{~Hz} .
$$

Using the frequency correction circuit (DA1, C3), the oscillation frequency is reduced to $10 \mathrm{kHz}$.

The aim of the research experiment part is to find the temperature error equation (7) for a generator with a Wien bridge. The ED's output parameter is the relative instability $\frac{\Delta f}{f}$ of the generation frequency. One-parameter ERE, most influencing the output parameter, are: C1, C2, C3, R2, R4.

The generator element base with the Wien bridge consists of four ERE types and four corresponding SPICE models (Table 1). For carrying out the computational experiment, the following ERE types are specified:

- for C1, C2 apply

ОСК10-17В-М47-1нФ $\pm 5 \%$ В ОЖ0.460.107 ТУ;

- for C3 apply

ОСК10-17В-М47-63пФ $\pm 5 \%$ В ОЖ0.460.107 ТУ;

- for R2, R4 apply

ОСМ Р1-8МП-0,5-10кОм $\pm 0,1$ \%-0,5-М-А-ОЖ0.467.164 ТУ.

According to $[11,12]$, the resistance temperature coefficient of the resistors' types is $\alpha_{R}= \pm 100 \cdot 10^{-6} \mathrm{C}^{-1}$; the capacitance temperature coefficient of the capacitors' types is $\alpha_{C}=-47 \cdot 10^{-6} \mathrm{C}^{-1}$. 
Table 1. SPICE model list used in the Wien bridge modeling

\begin{tabular}{|c|l|l|}
\hline No. & \multicolumn{1}{|c|}{ SPICE model name } & \multicolumn{1}{|c|}{ Origin source } \\
\hline 1 & Thin film chip resistor P1-8MП & $\begin{array}{l}\text { "SPICE-model development of Russian-made electronic } \\
\text { component base's library" report }\end{array}$ \\
\hline 2 & $\begin{array}{l}\text { Chip capacitor for surface mounting } \\
\text { К10-17B }\end{array}$ & $\begin{array}{l}\text { "SPICE-model development of Russian-made electronic } \\
\text { component base's library" report }\end{array}$ \\
\hline 3 & Silicon zener KC156A & $\begin{array}{l}\text { r-diod.lib library, part of the Spectrum Sofware } \\
\text { MicroCAP simulator (Russian localized version) [13] }\end{array}$ \\
\hline 4 & $\begin{array}{l}\text { Medium accuracy operational amplifier } \\
\text { К153УД6 }\end{array}$ & $\begin{array}{l}\text { r-opamp2.lib library part of the Spectrum Sofware } \\
\text { MicroCAP simulator (Russian localized version) [13] }\end{array}$ \\
\hline
\end{tabular}

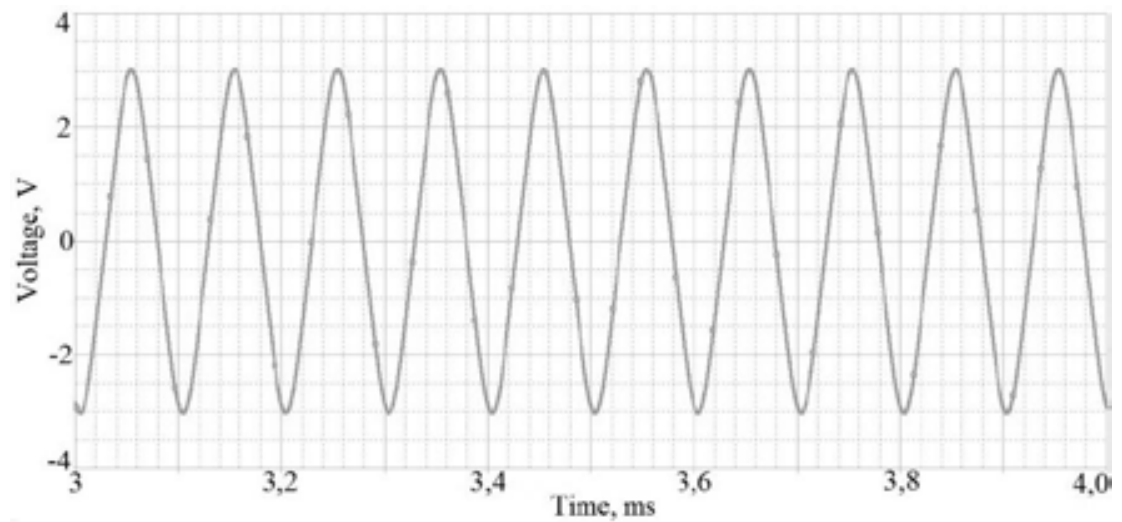

Fig. 5. Oscillation generation in the nominal mode $\left(f=10 \mathrm{kHz}, U_{m}=3 \mathrm{~V}\right)$

In the nominal mode (no parameters' variation), the simulation of the generator's circuit with the Wien bridge was carried out in the OrCAD PSpice simulator [14]. The result were harmonic oscillations of $f=10 \mathrm{kHz}$ frequency and $U_{m}=3 \mathrm{~V}$ amplitude (Fig. 5).

To accurately fix the $f$ and $U_{m}$ numerical values the PSpice Probe graphic postprocessor two target functions are formed:

\section{1/Period(V(DA1:OUT)); \\ $\operatorname{Max}(\mathrm{V}(\mathrm{DA} 1: \mathrm{OUT}))$,}

where Period - is the target function template for finding the oscillation period [14]; Max - is the target function template for finding the oscillation amplitude [14]; V (DA1: OUT) - is the target functions' argument, denoting the potential at the OUT output of the DA1 operational amplifier (and the whole circuit).

The main characteristics of the computational experiment plan are given in Tables 2, 3, 4. Note that the capacitor types used have a linear capacitance temperature coefficient (M47) over the entire operating temperature range [12]. The resistor type has a non-linear resistance temperature coefficient (M) [11], however, due to the small temperature range in the computational experiment $\left( \pm 10{ }^{\circ} \mathrm{C}\right)$, it is permissible to use a linear dependence. Thus, during computational experiment planning the parameter's temperature dependence was used for all variable ERE: 


$$
N(T)=N_{0}(1 \pm T C N \cdot \Delta T),
$$

where $N_{0}$ - is the nominal parameter value; $T C N$ - is the parameter's temperature coefficient; $\Delta T= \pm 10^{\circ} \mathrm{C}$ - variation interval temperature.

Based on the results of the computational experiment planning, the relative deviation (DEV) of the ERE's scale parameter is found necessary for the Monte Carlo statistical tests (the penultimate column):

\section{.MODEL K10-17 CAP $(\mathrm{C}=1 \mathrm{DEV}=0.047 \%)$; \\ .MODEL R1-8 RES ( $\mathrm{R}=1 \mathrm{DEV}=0.1 \%)$.}

Table 2. Variation levels for C1, C2 (x1, x2 factors)

\begin{tabular}{|l|c|c|c|c|c|c|}
\hline & $\begin{array}{c}\text { Capacitor } \\
\text { operating } \\
\text { temperature } \\
T,{ }^{\circ} \mathrm{C}\end{array}$ & $\begin{array}{c}\text { Absolute } \\
\text { capacity value } \\
C_{\mathrm{ABS}}, \mathrm{nF}\end{array}$ & $\begin{array}{c}\text { Temperature } \\
\text { variation } \\
\text { interval } \\
\Delta T,{ }^{\circ} \mathrm{C}\end{array}$ & $\begin{array}{c}\text { Capacity } \\
\text { absolute } \\
\text { deviation } \\
\Delta C, \mathrm{nF}\end{array}$ & $\begin{array}{c}\text { Capacity } \\
\text { relative } \\
\text { deviation } \\
\frac{\Delta C}{C_{\mathrm{ABS}}} \cdot 100 \%\end{array}$ & $\begin{array}{c}C \text { scale factor } \\
\text { deviation } \\
\text { for the SPICE } \\
\text { model }\end{array}$ \\
\hline Top level & 37 & 1,00047 & +10 & $+0,00047$ & $+0,047$ & 1,00047 \\
\hline Zero level & 27 & 1 & 0 & 0 & 0 & 1 \\
\hline Bottom level & 17 & 0,99953 & -10 & $-0,00047$ & $-0,047$ & 0,99953 \\
\hline
\end{tabular}

Table 3. Variation levels for C3 (x3 factor)

\begin{tabular}{|l|c|c|c|c|c|c|}
\hline & $\begin{array}{c}\text { Capacitor } \\
\text { operating } \\
\text { temperature } \\
T,{ }^{\circ} \mathrm{C}\end{array}$ & $\begin{array}{c}\text { Absolute } \\
\text { capacity value } \\
C_{\mathrm{ABS}}, \mathrm{nF}\end{array}$ & $\begin{array}{c}\text { Temperature } \\
\text { variation } \\
\text { interval } \\
\Delta T,{ }^{\circ} \mathrm{C}\end{array}$ & $\begin{array}{c}\text { Capacity } \\
\text { absolute } \\
\text { deviation } \\
\Delta C, \mathrm{nF}\end{array}$ & $\begin{array}{c}\text { Capacity } \\
\text { relative } \\
\text { deviation } \\
\frac{\Delta C}{C_{\mathrm{ABS}}} \cdot 100 \%\end{array}$ & $\begin{array}{c}C \text { scale factor } \\
\text { deviation } \\
\text { for the SPICE } \\
\text { model }\end{array}$ \\
\hline Top level & 37 & 63,02961 & +10 & $+0,02961$ & $+0,047$ & 1,00047 \\
\hline Zero level & 27 & 63 & 0 & 0 & 0 & 1 \\
\hline Bottom level & 17 & 62,97039 & -10 & $-0,02961$ & $-0,047$ & 0,99953 \\
\hline
\end{tabular}

Table 4. Variation levels for R2, R4 (x4, x5 factor)

\begin{tabular}{|l|c|c|c|c|c|c|}
\hline & $\begin{array}{c}\text { Resistor } \\
\text { operating } \\
\text { temperature } \\
T,{ }^{\circ} \mathrm{C}\end{array}$ & $\begin{array}{c}\text { Absolute } \\
\text { resistance } \\
\text { value } \\
R_{\mathrm{ABS}}, \mathrm{Ohm}\end{array}$ & $\begin{array}{c}\text { Temperature } \\
\text { variation } \\
\text { interval } \\
\Delta T,{ }^{\circ} \mathrm{C}\end{array}$ & $\begin{array}{c}\text { Resistance } \\
\text { absolute } \\
\text { deviation } \\
\Delta R, \mathrm{Ohm}\end{array}$ & $\begin{array}{c}\text { Resistance } \\
\text { relative } \\
\text { deviation } \\
\frac{\Delta R}{R_{\mathrm{ABS}}} \cdot 100 \%\end{array}$ & $\begin{array}{c}R \text { scale factor } \\
\text { deviation } \\
\text { for the SPICE } \\
\text { model }\end{array}$ \\
\hline Top level & 37 & 10010 & +10 & +10 & $+0,1$ & 1,001 \\
\hline Zero level & 27 & 10000 & 0 & 0 & 0 & 1 \\
\hline Bottom level & 17 & 9990 & -10 & -10 & $-0,1$ & 0,999 \\
\hline
\end{tabular}


Multivariate analysis of the electrical circuit (Fig. 4) using the Monte Carlo method is carried out in the OrCAD PSpice simulator. The circuit simulation parameters (Fig. 6, 7) are:

- run to time: $\Delta t=4 \mathrm{~ms}$;

- start saving data after: $t_{\text {beg }}=3 \mathrm{~ms}$;

- skip the direct current analysis;

- output variable - output voltage of the op-amp: $U_{\text {OUT }}=V(D A 1: O U T)$;

- test number by the Monte Carlo method: $M C=100$;

- name of the random variables' distribution law: BiModal;

- random number seed: $N o=1$;

- coordinates of the normalized bimodal distribution law: $(-1,1)(-0.99,1)(-1,1)(-0.99,1)(-0.99,0)$ $(0.99,0)(0.99,1)(1,1)$.

The result of the multivariate analysis is the family of harmonic oscillations originally. However, such a graphical representation is inconvenient for perception and quantitative analysis. The noted deficiency is easily eliminated. The functionality of the PSpice Probe graphical postprocessor makes it possible to present the values of the target function (12) in a table form in each of the statistical tests (Fig. 8).

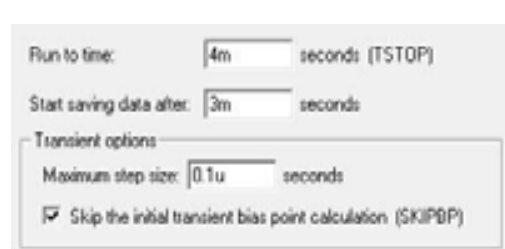

$a$

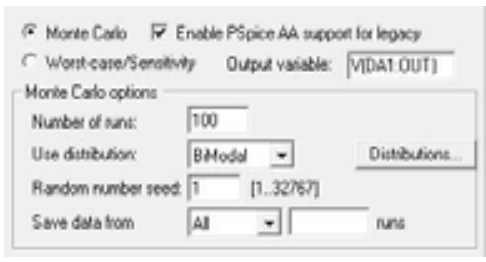

$b$

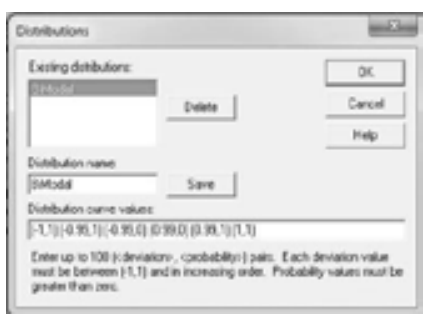

$c$

Fig. 6. Modeling parameters: $a$ - time domain analysis parameters, $b$ - Monte Carlo analysis parameters, $c-$ bimodal distribution parameters

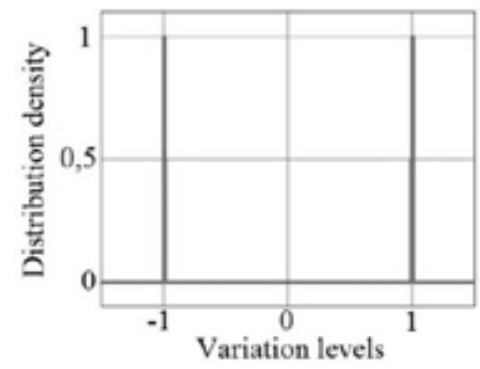

Fig. 7. The normalized density of the bimodal distribution

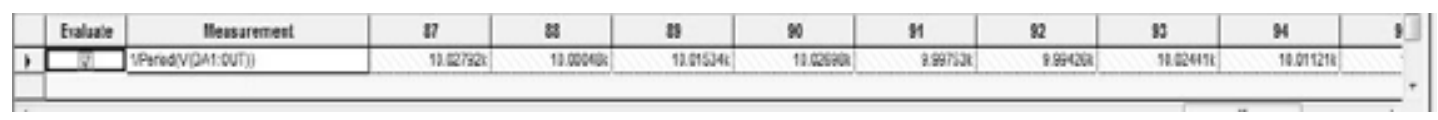

Fig. 8. Table of Monte Carlo test results 
Each of the statistical test's results (Fig. 8) should be compared with a specific combination of variable factors. The essence of the comparison lies in the comparative analysis of the output text file (Fig. 9, a) generated by OrCAD PSpice, and the information presented in the implementation matrix of the computational experiment (Fig. 9, $b, c$ ).

For example, in a text file, a fragment with test No. 87 was found, with the following combination of ERE parameters:

$$
\begin{aligned}
& \mathrm{C} 1=9,9953 \mathrm{E}-01 ; \mathrm{C} 2=9,9953 \mathrm{E}-01 ; \mathrm{C} 3=9,9953 \mathrm{E}-01 ; \\
& \mathrm{R} 2=9,9900 \mathrm{E}-01 ; \mathrm{R} 4=9,9900 \mathrm{E}-01 .
\end{aligned}
$$

According to Table 2, 3, 4 it is easy to establish that the code values of the factor combination looks like:

$$
\mathrm{C} 1=-1 ; \mathrm{C} 2=-1 ; \mathrm{C} 3=-1 ; \mathrm{R} 2=-1 ; \mathrm{R} 4=-1 .
$$

Therefore, the test No. 87 and the target function value $f=10,02792 \mathrm{kHz}$, found from the table in Fig. 8, will correspond to the combination $(-1-1-1-1-1)$ in the computational experiment implementation matrix.

The orthogonality of the implementation matrix's columns (Fig. 9, c) allows us to determine the regression coefficients according to (9) and (10):

$$
\begin{aligned}
& b_{0}=10,014 \cdot 10^{3} ; b_{1}=0,00146 \cdot 10^{3}(\mathrm{C} 1) ; b_{2}=-0,00587 \cdot 10^{3}(\mathrm{C} 2) ; \\
& b_{3}=-0,00046 \cdot 10^{3}(\mathrm{C} 3) ; b_{4}=-0,01248 \cdot 10^{3}(\mathrm{R} 2) ; b_{5}=0,00312 \cdot 10^{3}(\mathrm{R} 4) .
\end{aligned}
$$

Consequently, the linear polynomial has the form:

$$
f=\left(10,014+0,00146 q_{1}-0,00587 q_{2}-0,00046 q_{3}-0,01248 q_{4}+0,00312 q_{5}\right) \cdot 10^{3} .
$$

Using the obtained linear polynomial (12), we calculate the theoretical value of the output $f_{\mathrm{T}}$ parameter in each experiment, and then find the sum of the difference squares between the experimental and theoretical values of the output parameter. The total sum of difference squares of values for a linear polynomial is $\Delta f^{2}=4,96 \cdot 10^{-8} \cdot 10^{3}$. Taking into account the small value of $\Delta f^{2}$, we can consider (12) to be an adequate regression model.

According to (11), the coefficients of the temperature error equation are determined:

$$
\begin{aligned}
& a_{1}=0,311(\mathrm{C} 1) ; a_{2}=-1,247(\mathrm{C} 2) ; \\
& a_{3}=-0,097(\mathrm{C} 3) ; a_{4}=-1,247(\mathrm{R} 2) ; a_{5}=0,312(\mathrm{R} 4) .
\end{aligned}
$$

The temperature error equation in accordance with (7) will be:

$$
\begin{gathered}
\frac{\Delta f}{f}=1,46 \cdot 10^{-5} \Delta T_{C 1}-5,86 \cdot 10^{-5} \Delta T_{C 2}-4,55 \cdot 10^{-6} \Delta T_{C 3}- \\
-1,25 \cdot 10^{-4} \Delta T_{R 2}+3,12 \cdot 10^{-5} \Delta T_{R 4} .
\end{gathered}
$$

\section{Research results}

Analysis (13) allows us to state:

- the temperature error of the generation frequency mainly depends on the temperature instability of the four ERE: $\mathrm{C} 1$ and $\mathrm{C} 2$ capacitors, R2 and R4 resistors; 
- the linear polynomial (12) is recognized as an adequate regression model of the investigated process;

- to ensure a given temperature stability of the generator, three solutions are possible: the use of highly stable $\mathrm{C} 1, \mathrm{C} 2, \mathrm{C} 3, \mathrm{R} 2$, R4; partial temperature compensation of $\mathrm{C} 1-\mathrm{C} 2$ and $\mathrm{R} 2-\mathrm{R} 4$ pairs; thermostating R4.

\section{Conclusions}

1. A modification of the numerical Monte Carlo method for analyzing the temperature stability of electronic circuits is proposed.

2. The problem of finding the influence coefficients of the temperature error equation for the oneparameter ERE's case was solved.

3. The obtained temperature error equation of the generator with the Wien bridge (13) allows quantitatively and qualitatively to formulate the requirements for ensuring a given temperature stability of the device both at the stage of circuitry and at the stage of topological design.

\section{References}

[1] Гусев В.П. и др. Расчет электрических допусков радиоэлектронной аппаратуры. М.: Сов. радио, 1963. 368 с. [Gusev V.P. and etc. Calculation of electrical tolerances of radio electronic equipment, Moscow, Sovetskoe radio, 1963, 368 p. (in Russian)].

[2] Фомин А.В., Борисов В.Ф., Чермошенский В.В. Допуски в радиоэлектронной аппаратуре. М.: Сов. радио, 1973. 128 с. [Fomin A.V., Borisov V.F., Chermoshenskiy V.V. Tolerances in radio electronic equipment, Moscow, Sovetskoe radio, 1973, 128 p. (in Russian)].

[3] Алексеев В.П. Стабилизаиия параметров радиотехнических устройств и систем на основе микротермостатирования, автореф. дис. ... канд. техн. наук. Томск, 1985. 20 с. [Alekseev V.P. Stabilization of the parameters of radio engineering devices and systems based on micro-thermostating, Thesis ... cand. of tech. Sci. Tomsk, 1985. 20 p. (in Russian)].

[4] Озеркин Д.В. Анализ и синтез термостабильныхрадиотехническихустройств, автореф. дис. ... канд. техн. наук. Томск, 2000. 24 c. [Ozerkin D.V. Analysis and synthesis of thermostable radio engineering devices, Thesis ... cand. of tech. Sci. Tomsk, 2000. 24 p. (in Russian)].

[5] Озеркин Д.В., Русановский С.А. Регрессионный анализ в исследовании температурной стабильности электронных схем. Динамика сложных систем - ХХІ век, 2017, 11(1), 65-72 [Ozerkin D.V., Rusanovskiy S.A. Regression analysis in the research of the temperature stability of electronic circuits. Dynamics of Complex Systems - 21 th century, 2017, 11(1), 65-72 (in Russian)].

[6] Бусленко Н.П., Шрейдер Ю.А. Метод статистических испытаний (Монте-Карло) и его реализачия на иифровых вычислительных матинах. М.: Физматлит, 1961. 228 с. [Buslenko N.P., Shreyder Yu.A. The method of statistical tests (Monte-Carlo) and its implementation on digital computers, Moscow, Fizmatlit, 1961, 228 p. (in Russian)].

[7] Озеркин Д.В., Русановский С.А. Методология моделирования температурной стабильности резисторных блоков Б19К в SPICE-подобных симуляторах. Доклады ТУСУРа, 2017, 20(2), 49-54 [Ozerkin D.V., Rusanovskiy S.A. Methodology for modeling the temperature stability of the B19K resistor blocks in SPICE simulators. Proceedings of TUSUR, 2017, 20(2), 49-54 (in Russian)]. 
[8] Озеркин Д.В., Русановский С.А. Автоматизация проектирования SPICЕ-моделей резисторных блоков Б19К с позиции температурной стабильности. Вестник Воронежского государственного технического университета, 2017, 13(4), 90 -97 [Ozerkin D.V., Rusanovskiy S.A. SPICE model automatic designing of Б19K resistance blocks from the position of temperature stability, The Bulletin of Voronezh State Technical University, 2017, 13(4), 90-97 (in Russian)].

[9] Справочник по элементам радиоэлектронных устройств / Под ред. В.Н. Дулина, М.С. Жука. М.: Энергия, 1977. 576 с. [Handbook of Elements of Radioelectronic Devices, Edited by V.N. Dulin, M.S. Zhuk. Moscow, Energia, 1977, 576 p. (in Russian)].

[10] Tobey G.E., Graeme J.G. Operational Amplifiers: Design and Applications. McGraw-Hill, 1971. $512 \mathrm{p}$.

[11] P1-8МП. ОАО НПО «Эркон» [Электронный ресурс]. Режим доступа: http://www.erkonnn.ru/catalog/9/r1-8mp1/ [R1-8MP. NPO Erkon, JSC [Electronic resource]. Access: http://www.erkonnn.ru/catalog/9/r1-8mp1/].

[12] ОАО Кулон. Конденсаторы К10-17в [Электронный ресурс]. Режим доступа: http://www. kulon.spb.ru/katalog-produktsii/kondensatory/k10-17v [Kulon, JSC. K10-17v capacitors [Electronic resource]. Access: http://www.kulon.spb.ru/katalog-produktsii/kondensatory/k10-17v].

[13] Spectrum Software - MicroCAP 11. Analog simulation, mixed mode simulation, and digital simulation software [Electronic resource]. Access: http://www.spectrum-soft.com/index.shtm

[14] Overview Page - OrCAD PSpice Designer. OrCAD [Electronic resource]. Access: http:// www.orcad.com/products/orcad-pspice-designer/overview

[15] Nagel L.W., Pederson D.O. SPICE (Simulation Program with Integrated Circuit Emphasis). Berkeley, University of California, 1973. 65 p. 